\title{
8. Support to enterprise development and entrepreneurship education
}

\subsection{IMPORTANCE OF ENTREPRENEURSHIP AND BUSINESS SECTOR ORIENTATION FOR INNOVATION}

One of the key assumptions underlying regional innovation policies is that universities can act as entrepreneurial actors (Power and Malmberg, 2008; Audretsch, 2014). Entrepreneurship-driven RII is likely to materialise when universities initiate economic activities or are actively engaged with business sector partners. Such connections and interactions may involve numerous organisational vehicles, mechanisms, and channels (Mustar, 2002). Supplementing the various 'transfer' mechanisms mentioned in the previous chapter, this chapter focuses its attention on entrepreneurship training and support to enterprise development in general.

To prepare their graduates for a society and economy - both domains characterised by increasing complexity, variability, and uncertainty - universities increasingly aim to provide students a suitable learning environment for those who want to start their own business venture, as well as for students that want to experience the pros and cons of being entrepreneurially engaged. As such, universities can support entrepreneurship and enterprise development in their local or regional environment. That process of creating such RII resources and RII pathways usually starts with provision of entrepreneurship education, mostly by conferring the skills, aptitude and mind-set that will enable these individuals to develop new and innovative plans (Jones and English, 2004).

Entrepreneurship includes creativity, innovation and risk-taking, as well as the ability to plan and manage projects that achieve objectives. Proactively equipping their students (or staff) with an entrepreneurial attitude and sufficient entrepreneurship competences enhances their propensity to take calculated risks and start new initiatives. During 'venture creation programmes' (Ollila and Williams-Middleton, 2011; Lackéus and Williams-Middleton, 2015; Boh et al., 2016) students have to think and act as entrepreneurs, creating real-life ventures as part of the formal curriculum. Throughout the process, mistakes are valued since they are seen as opportunities for reflection 
and learning. Students also attempt to engage other internal (academics) and external (practitioners, investors) stakeholders in their venture creation (Ollila and Williams-Middleton, 2011). Another very powerful strategy for student deep learning (Bovill et al., 2011) is the practice of involving students to lead or design educational programmes.

Offering students a dedicated platform to pitch their plans and ideas to companies and potential investors can also be an important part of fostering entrepreneurship. When university students or staff become 'entrepreneurial' and 'innovative', they may interact with business of all sorts; from SMEs to large multinationals, and century-old established enterprises. Some of these firms are likely to be either a university 'spin-off' or 'start-up' firms (spin-offs are supported by university-owned intellectual property; start-ups are not). Innovation-oriented entrepreneurship may lead to new products and services with potential value for commercialisation in the regional economy and creation of significant levels of RII.

However, entrepreneurship is more than learning the skills to setting up or running a business venture; it refers to the generic capacity to act upon ideas and opportunities to generate social, economic, and cultural value. Entrepreneurial activities might involve the knowledge and the skill set of multiple fields of knowledge. Such 'entrepreneurial human capital' does not necessarily only prove its value in the number of new business enterprises that were launched or other economic ventures. Entrepreneurship competences can be employed in almost any circumstance and profession, including in not-for-profits, government organisations, the education sector, and in large enterprises. In other words, having entrepreneurship skills also helps to empower university graduates or staff members to pursue self-directed career management.

This chapter is specifically dedicated to the 'RII delivery space' of universities, in particular its RII pathways. Section 8.2 describes initiatives, activities and pathways related to entrepreneurship education, while section 8.3 presents examples of how universities may support business enterprise development. The concluding section summarises the main findings and draws some general conclusions.

\subsection{RII DELIVERY SPACE: ENTREPRENEURSHIP TEACHING AND TRAINING}

Entrepreneurship courses are designed to raise awareness with regards to the possibility of becoming an entrepreneur - either as a student or after graduation. Over the last two decades, many research-active universities have introduced entrepreneurship courses and facilities for student-led entrepreneurial activities, which may attract talented students, entrepreneurs, and investors. Some of the universities represented in our case studies have set explicit 
targets in their visions for the near future. Aalborg University's vision for the next strategic period (2021-2026) states: "all students must graduate with the knowledge and skills to create their own company" and "a goal is to create 1000 entrepreneurs" (see Appendix C, section C.5).

Various teaching approaches are used by entrepreneurship education providers, such as Problem-Based Learning (PBL) as described in Box 5.2 (section 5.2). The University of Strathclyde's Hunter Centre runs Enterprise Clinics, delivered by cross-disciplinary teams of Business School students who conduct research and consultancy projects for local businesses facing specific challenges. Aalto University has introduced the Berkeley Method of Entrepreneurship to develop new teaching models. Aalto University's entrepreneurship programmes build on entrepreneurship-related collaboration with the University of California Berkeley and Stanford University (both pioneers in university-based innovation systems). The Aalto Ventures Programme offers its students entrepreneurship courses - taught by professors, venture capitalists, and entrepreneurs - with a focus on building scalable businesses.

Integrating entrepreneurship education in the curriculum of other study programmes is a common feature in many universities. For instance, the University of Leuven offers entrepreneurship courses to bachelor as well as master students. It's LCIE academy portfolio is created so that students are required to take a variety of courses from different faculties, thereby promoting interdisciplinarity as one of the core values of innovation-driven entrepreneurship (LCIE is KU Leuven's 'Community for Innovation driven Entrepreneurship'). Another initiative was developed by students from the law faculty of the Catholic University of Leuven who established IusStart, a legal clinic run by $\mathrm{PhD}$ students, in which law students as part of their studies provide legal advice to other students who work on the development of their start-up firms. Similarly, technology advice is shared by $\mathrm{PhD}$ students from the engineering faculty under the 'TechStart' project. When rolling out the student incubator activities at the Catholic University of Leuven, it was decided to provide facilities for student-entrepreneurs in a decentralised way, across the various campuses. The facilities include a 'fab lab', providing students with the necessary prototyping tools. Students interested in entrepreneurship can access a 'creativity lab' where they can meet and work on their business plan. Office space at an incubator facility, which is shared with young start-up companies, allows students to interact with other entrepreneurs. See Appendix B for more information on this university's activities with regard to entrepreneurship teaching and training.

Each university has its own organisational structure to facilitate entrepreneurship education and training. Not only does Aalborg University offer more than 100 different courses or study programmes on entrepreneurship for students, entrepreneurial activities are also incorporated in the regular curricula to 
prepare students for work in the business sector. Aalborg University's business developers worked with many students (see Appendix C).

By way of its European Innovation Academy, the Technical University of Turin hosts an intensive summer entrepreneurship school in which about 500 international students (including its own students), guided by renowned mentors and with the sponsorship of multinational firms and international organisations, are challenged to transform their ideas into technology start-ups while working in a multidisciplinary and international team (see Appendix D). The Technical University of Catalunya runs an initiative called an Innovation Office that aims to foster an entrepreneurial culture among students and help them create new tech-based companies.

Another example is the Centre for Entrepreneurship established by Warsaw University, which, among other activities supporting entrepreneurial education, hosts the annual international conference on entrepreneurship that gathers both business and academic communities. The University's Technology Transfer Centre also launched the UW Incubator (IUW) dedicated to supporting entrepreneurial skills among students and alumni as well as accommodating entrepreneurial ideas of staff. A network of faculty ambassadors was created for 21 departments and almost 100 mentors were invited to support students' ideas. IUW offers science-business co-working space and development of social entrepreneurship facilities for students (see Appendix E). The University of Ruse's Centre for Entrepreneurship Promotion, in cooperation with its Technology Transfer Office, runs an Entrepreneurship Development programme which is supported by a variety of funding sources. Start-up training is open to all students, regardless of their degree programme, offering several business start-up courses. Over the last three years, the university has also initiated and organised the Innovative Youth EXPO, where student teams present their innovative ideas and developments. The Innovation Lab at Eötvös Loránd University's Faculty of Informatics is another example of a facility specifically designed to assist the development of innovative entrepreneurial ideas of students (and university staff). Participants can start their own start-up projects or may join other start-ups to develop entrepreneurial ideas. The University of Bologna supports entrepreneurial ideas of their students during its StartUp Days, a round table during which the students of pre-selected projects pitch their ideas to regional, national, and even foreign investors. The annual series of these events (held since 2015) involves 838 start-up projects, 126 of which received customised support and 100 entered the incubation programmes of AlmaCube. So far, more than $€ 3$ million have been raised by the companies that participated in StartUp Day events.

Experienced coaches are essential to nurture student entrepreneurship. Leiden University's ELF pre-seed fund gives students access to a network of relevant experts and contacts in Dutch and international companies and 
organisations, both within and outside Leiden. These experienced business people help them to let their idea grow, and can provide them with the financial and physical resources to turn their business idea into a solid business plan. The Norwegian University of Science and Technology launched Spark*, a student-driven extracurricular entrepreneurship initiative. All university students with an idea they want to set to life are eligible for free coaching by students with some previous entrepreneurial experience (e.g. owners of start-ups) or by its senior staff. So far, the initiative has offered coaching to over 360 projects and supported over 1100 students. Among the projects 36 have been turned into businesses. Mentoring can be provided both by senior students or staff as in the GUIDED programme at Kaunas University of Technology which involves an educational partnership between a motivated student and a more experienced and competent mentor. One of the most valued aspects of university support for student-entrepreneurs is access to facilities such as meeting rooms and workplaces. In 2017 the University of Trieste launched a contamination-LAB with $1000 \mathrm{~m}^{2}$ of co-working space where students can develop entrepreneurship skills. Some universities have joined forces with other regional partners to provide its students with the necessary entrepreneurship skills: Leiden University, the municipality of Leiden and the University of Applied Sciences in Leiden have jointly set up a pre-incubation facility called PLNT, which hosts courses and events for and by students aimed at fostering innovation and entrepreneurship. PLNT also houses start-ups and professionals who can support student entrepreneurs.

\subsection{RII DELIVERY SPACE: SUPPORTING ENTERPRISE DEVELOPMENT}

The available support structures at universities differ significantly in size and scope. Some are large and have evolved for several decades, while others are relatively new and small. The Catholic University of Leuven has invested substantially in its own science parks, business centres and incubators since the mid-1990s. The university's 'Leuven Technology Corridor' comprises several locations, all in the immediate vicinity of Leuven. The Arenberg Science park is located next to the science campus, covers 13 hectares and will ultimately consist of four clusters, each offering $25000 \mathrm{~m}^{2}$ of working space. The Catholic University of Leuven has spun-off no less than 124 companies during the years 1979-2017. In the period 2005-2017, the university invested $€ 32.9$ million in its spin-offs, while third-party investors matched this with $€ 926.5$ million. These new venture creation activities have resulted in about 6700 new jobs. See Appendix B for more details about the Catholic University of Leuven's achievements. 
Some of the other research-active universities have also generated significant numbers of new jobs in the local region. The Technical University of Milan's PoliHub company provides support to high innovative start-ups. Since its foundation in 2000, it has collected more than 10300 innovative ideas and it has supported about 450 of them in their start-up phase with a survival rate of $85 \%$. Collectively, these start-ups have generated a cumulative turnover of $€ 30$ million and have employed over 550 people.

In 1998, the Technical University of Catalunya launched the Innova Programme (now the Innovation Office) to support the creation of technology-based companies and promote a culture of entrepreneurship and innovation. Of the 300 companies created during the last ten years, 80 are university spin-offs. The university holds an equity stake in 28 of them, representing an amount of $€ 36$ million; these companies employ about 300 people. Another 150 tech companies are being incubated in its Research and Innovation Park, which employ 4000 people, $60 \%$ of whom are graduates and $\mathrm{PhD}$ holders.

Another example is I3P at the Technical University of Turin. I3P is the university's non-profit joint-stock consortium that includes the Turin Chamber of Commerce, the City of Turin and the Province of Turin as shareholders. I3P has been successful in introducing new companies with a significant impact on the local economy and on employment: total turnover and employment stood at $€ 124$ million and 1687 jobs in 2016 (see Appendix D). The University of Trieste's spin-off companies are located in Area Science Park or in the Business Innovation Centre. At the end of 2017 it had 20 active spin-offs, with a turnover of almost $€ 11$ million in 2016 and directly employing more than 130 people.

Although sheer volume is not indicative of commercial success or economic impact, the number of spin-offs and start-ups may partially reflect a university's RII performance. The University of Bologna has produced 67 spin-offs between 2000 and 2013, Aalto University managed to produce about 70 start-ups annually between 2010 and 2014, up to around 100 in the most recent years $(50 \%$ of all start-ups originating from Finnish research-active universities annually). The University of Strathclyde's Hunter Centre for Entrepreneurship, collaborating closely with its TTO (Research \& Knowledge Exchange Services) and the Strathclyde Entrepreneurial Network, has helped to support the formation of over 150 companies through its Enterprise Hub since 2005.

Business incubators and accelerators are important facilitators in a university's RII delivery space. Validé, the University of Stavanger's TTO and incubator centre, handled 50 new companies. Two business exits were carried out in 2017, which resulted in a sale of NOK 11.4 million in shares. University of Aveiro's Business Incubator (IEUA), created in 1996, develops activities that 
allow the conversion of knowledge into economic value, providing a business incubation programme (IEUA Start) and a business acceleration programme (IEUA Graduate). In 2017 IEUA developed 30 companies, of which 27 were in incubation or acceleration stages and responsible for a turnover of $€ 8.8$ million and 153 jobs. The University of the Basque Country hosts six business incubators in the three Basque provinces (three in Biscay, two in Gipuzkoa, and one in Araba) and each year allocates $€ 12000$ in prizes to award the most innovative ideas and the best university entrepreneurship projects.

\subsection{CONCLUSION}

A university's economic impact is intricately linked to its ability to foster 'knowledge intensive entrepreneurship' (Malerba et al., 2015). Developing an entrepreneurial mind-set and skill set is a necessary condition to prepare university students and staff for setting up companies or gaining employment in the business sector. Innovation is, ultimately, about the human factor, about individual entrepreneurship, creativity, and persistence.

Several universities are genuine 'engines of innovation' in terms of producing spin-off and start-up companies over the years, with many new jobs created in knowledge-based industries. The examples, however, also underline the major importance of physical infrastructures and dedicated facilitators within RII delivery spaces, such as science parks, business incubators and business accelerators. Successful RII delivery spaces require dedicated human capital and effective physical capital. Adequate funding and targeted policies are the other two pillars; these are the main topics of Part III. 